\title{
14 \\ On the Cultural History of the Aru Islands: Some Conclusions
}

\author{
Sue $0^{\prime}$ Connor ${ }^{1}$, Matthew Spriggs ${ }^{1}$, and Peter Veth ${ }^{2}$ \\ 1. Department of Archaeology and Natural History, Research School of Pacific and Asian Studies, \\ The Australian National University, Canberra, ACT, Australia \\ 2. Research Unit, Australian Institute of Aboriginal and Torres Strait Islander Studies, Canberra, ACT, Australia
}

\begin{abstract}
My expedition to the Aru Islands had been eminently successful...I brought away with me more than nine thousand specimens of natural objects, of about sixteen hundred distinct species. I had made the acquaintance of a strange and little-known race of men; I had become familiar with the traders of the far East; I had revelled in the delights of exploring a new fauna and flora, one of the most remarkable and least-known in the world; and I had succeeded in the main object for which I had undertaken the journey - namely, to obtain fine specimens of the magnificent birds of paradise, and to be enabled to observe them in their native forests. By this success I was stimulated to continue my researches in the Moluccas and New Guinea for nearly five years longer, and it is still the portion of my travels to which I look back with the most complete satisfaction.
\end{abstract}

Wallace 1869:486

In the introduction to this volume (Chapter 1) we discussed the specific objectives of the Aru Islands research project and how these were framed within the context of broader regional themes and issues that have directed, and continue to direct, archaeological enquiry within Island Southeast Asia, Australia, and elsewhere in Oceania. Here we review the results of our field work and analysis in the context of these broad research questions.

Specifically we had hoped to find archaeological evidence in the Aru Islands that would throw light on the following issues:

1) the nature and rate of maritime colonization and island settlement by early $H$. sapiens sapiens in the Pleistocene, and the subsequent impact of such settlement on the 'pristine' landscapes of previously unoccupied islands;

2) the extent of inter-island connectivity or isolation, and contact and exchange in the Pleistocene and early Holocene, as demonstrated by the evidence relating to the translocation of animal species, plants and exotic stone; 
3) the origins and timing of the introduction of agriculture and domestic animals, and the impetus for the development and/or adoption of agriculture by pre-agricultural communities or hunter-horticulturalists;

4) the interaction between indigenous groups and incoming Austronesian settlers and/or traders; and

5) the involvement of Aru as a supplier of bird of paradise feathers and other forest and marine products to world markets over the last 2000 years or so.

As is often the case when research is initiated in a previously unexplored area, our endeavours met with mixed success: positive results in some areas which were unanticipated and little information about other issues or periods of time that we thought would almost certainly be productive. These are reviewed in chronological succession.

\section{The Timing and Nature of Maritime Colonization, Island Settlement and Evidence for Inter-Island Connectivity in the Pleistocene and Early Holocene}

As discussed in Chapter 1, the dates for the first peopling of Sahul or Greater Australia have now been pushed back to about 55,000 to 65,000 years ago. These dates result from the application of techniques such as TL, OSL, and ESR, which are capable of dating materials that are well beyond the range of radiocarbon chronology. Using these techniques, early dates have now been obtained from open and shelter site types in both northern and southern Australia (see O'Connor and Chappell 2003 for a summary of results and the debate). For a variety of reasons, however, some researchers are still reluctant to accept these early dates and prefer to rely on the radiocarbon chronology (Allen and O'Connell 2003). However, even if we rely exclusively on the radiocarbon chronology, an arrival date of ca. 50,000 BP seems overly conservative, in view of the fact that radiocarbon dates of the order of 47,000 $\mathrm{BP}$ have been obtained for early occupation levels in the southwest of the continent (Turney et al. 2001). Occupation of what is now northeastern New Guinea occurred at least 40,000 years ago (references in O'Connor and Chappell 2003), and the islands to the east of New Guinea requiring further water crossings were also first settled by at least 40,000 BP (Leavesley and Chappell 2004).

In Island Southeast Asia beyond the Sunda Shelf the oldest dates published for modern human occupation so far are those from Lene Hara cave in East Timor at 35,000 years (O'Connor et al. 2002). In Halmahera and Sulawesi earliest occupation dates are between 28,000 and 31,000 years BP (Bellwood et al. 1998; Glover 1981). The remarkable discoveries in Flores relate to a much earlier mid-Pleistocene settlement, seemingly by Homo erectus populations who may later have evolved into the diminutive Homo floresiensis (Brown et al. 2004; Morwood et al. 1998, 1999, 2004). Early occupation of that island by Homo sapiens is very likely but as yet undocumented.

The combined evidence available to us in 1995 suggested that evidence of modern human settlement in Wallacea in the order of at least 40,000 to 45,000 years BP should be forthcoming, and Aru seemed like a good candidate for discovering early settlement.

As already mentioned, the Aru Islands looked to be a logical field target for investigating initial and subsequent maritime colonizations into Sahul. First, their location on the edge of the Sahul shelf appeared optimal in terms of detecting initial Pleistocene colonization (Chapter 1:Figure 1.1; cf. Birdsell 1977). Secondly, the narrow water channel between the southeastern Moluccan islands and the edge of the Sahul shelf at this point (the Aru Plateau) would also have facilitated two-way voyaging. Given the steeply shelving submarine profile to the west, there seemed a good chance that Pleistocene/ early Holocene archaeological sites would be found not far 
inland from the present coast, in limestone caves with well preserved faunal and botanical remains that would enable us to track faunal translocation and extinction events.

The field survey carried out in 1995 demonstrated that suitable limestone caves were not to be found on the west coast. This meant that we had no promising sample points in the areas assessed to have greatest potential for uncovering initial colonization. We then turned our attention to the inland karst limestone areas, which produced a wealth of caves, and the two most promising were selected for excavation in the subsequent field seasons: Liang Lemdubu in 1996 and Liang Nabulei Lisa in 1997.

The 1995-97 investigations provide no support for colonization onto the Sahul Shelf by early maritime colonists making their way through the island chain around 50,000 years ago or earlier (Birdsell's (1977) route 2A). As discussed in Chapter 9, the excavation at Liang Lemdubu produced a rich Pleistocene record of human occupation, but one confined to the past 28,000 years, with little evidence available for the period after the beginning of the Holocene. Occupation at Liang Nabulei Lisa begins about 16,000 years ago and fills in the terminal Pleistocene and early Holocene picture which is missing in Liang Lemdubu. The cave faunas are rich and well preserved, and provide an excellent record of changes in species distributions through time. Changes that occur during the late Pleistocene and early Holocene appear to reflect changes in the vegetation structure of the surrounding site environment, rather than to relate to human agency such as translocation of wild animals, changing predation patterns, or hunting pressure. Perhaps the principal contribution of the Aru faunal record is as a proxy for past vegetation change and inferred climate change on the Aru Plateau in the late Pleistocene and early Holocene.

As discussed in Chapter 2, most of the vegetation records in this region are based on pollen and charcoal recorded in marine and terrestrial cores. The catchments for these records are broad and subject to a variety of influences. It is thus often difficult to apply the data obtained from them at the local scale. The complex relationships between land mass, altitude, wind circulation patterns, and sea surface temperature also make it difficult to model the impact of climate change at the local level. For this reason, there is disagreement amongst specialists about the severity and impact of cooling and aridity at different latitudes and altitudes during the LGM. It is at the local scale that change may be most influential in terms of human choices about whether or not occupation of a region is sustainable.

The composition of the vertebrate fauna in the earliest human occupation levels at Lemdubu suggests that the dominant vegetation in the vicinity of the cave was relatively dry and open, probably savannah woodland with a grassy understorey. This supported a range of species found today in the Trans-Fly area of New Guinea and across northern Australia, including Macropus agilis, Isoodon macrourus, and Rattus sordidus. However, in the same levels, a smaller but significant contribution is made by species which inhabit rainforest or dense gallery forest (i.e. Thylogale spp., Dorcopsis sp., Echymipera rufescens, Poponomys sp., Spilocuscus maculatus and Phalanger spp.), indicating that substantial patches of wetter, denser vegetation were still to be found in the vicinity of the site. Presumably these wetter plant communities were located along drainage lines and in topographic lows in the karst landscape.

Grassland-associated taxa increase and wet closed forest associated species decrease after this time, with a peak in open grassland species occurring about $20,000-17,000$ years ago. The faunal evidence for extensive and sustained savannah grassland from 28,000 years ago until the terminal Pleistocene/early Holocene at both Lemdubu and Nabulei Lisa tends to support the palaeoenvironmental models that propose more extreme cooling and reductions in precipitation at low altitude in this tropical region, with drops in temperature of up to 5-6 degrees during the glacial maximum, rather than the more conservative estimates (see Hope 2001:143). In general, the Aru faunal data fit well with the broad vegetation and inferred climate change derived from the most recently obtained palaeobotanical records (Hope et al. 2004; Kershaw et al. 2002). 
Although it is easy to see why the drier conditions associated with the onset of the LGM would have created favourable habitats for a range of human prey species on the Plateau, it is more difficult to understand why it was that Lemdubu was not occupied, even intermittently, prior to 28,000 years ago. It was suggested in Chapter 9 that slightly wetter conditions and more closed vegetation communities may have prevailed prior to this time, and that the Aru Plateau may have been a less bountiful environment for human occupation than subsequently, when savannah grassland was more extensive. Although this is no doubt the case, there is little evidence in the Banda core or other regional records to support the contention that rainforest would have been sufficiently dense to have acted as a barrier to human exploitation of the area surrounding Lemdubu in the 10,000 years preceding its first settlement (see Kershaw et al. 2002).

At this stage it must remain an open question whether or not hunter-gatherers were on the Aru Plateau prior to 28,000 years ago. It seems likely that the Aru dates reflect limited regional sampling of sites or of the extensive cave deposits of the island group. Discussion of other aspects of human occupation such as exchange or technology is hampered by the limited number of stone and bone artefacts in Lemdubu and Nabulei Lisa. Neither site provides any indication of changing technology prior to the introduction of pottery in the late Holocene. It is salutary to contemplate what we would have made of these two important cave sites if we had not had the excellently preserved faunal remains. We would no doubt have come to the conclusion that the caves were only occupied on a very fleeting basis during the late Pleistocene and the Holocene.

One find from Lemdubu may well give us a picture of what the earliest modern humans to reach northern Sahul would have looked like. This was the 18,000 BP burial of a female discussed in detail in Chapter 12. Lemdubu Woman is the earliest northern Sahulland skeleton, albeit dating from a time long after first human settlement of the region. The skeleton therefore probably displays evolution in body form from the initial inhabitants, currently best represented by the Mungo 1 and 3 skeletons from western New South Wales that date to in excess of 40,000 BP (Bowler et al. 2003, Thorne et al. 1999). The completeness of the Lemdubu skeleton, especially the pelvis, allowed its identification as a woman although the robustness of the skull would on its own have suggested the skeleton to be male. The discovery, when compared with other Sahul skeletons of approximately the same period, suggests that at the end of the LGM the inhabitants continentwide were already characterized by a distinctive suite of 'Australoid' features. They differed from modern Australian Aborigines in having a larger, more robust cranium. Most individuals, however, would have combined robust and more gracile traits. This suggests that the classic distinction made between robust and gracile populations within Pleistocene Sahul (Thorne 1980, 1989) is a false one, and that there was basically a single population evolving through time, with extensive gene flow between north and south.

\section{East to West or West to East? The Origins and Timing of the Introduction of Agriculture and Domestic Animals in Southeastern Maluku, and Interaction Between Indigenous Groups and Incoming Austronesian Settlers}

At the time we began this project there were two major competing hypotheses relevant to a consideration of the origins of horticulture in this region. The orthodox view had domesticated crops and animals - pigs, dogs and chickens - brought by Austronesian language speakers who also introduced pottery technology, approximately 3500 years ago. There was evidence to support this migration and diffusion from other areas of Island Southeast Asia, including Halmahera (updated references are provided by Bellwood 1997, Bellwood et al. 1998). The alternative view, gaining strength recently with the work of Denham and his colleagues at Kuk in the New Guinea Highlands (Denham 2003; Denham et al. 2003), stresses the independent development of agriculture in the New 
Guinea region and the spread to the west into Island Southeast Asia, as well as to the east into the Pacific, of a range of locally domesticated tuber and tree crops (cf. Spriggs 1996).

Related to this issue and also central to our investigation were the claims for the introduction of pigs into New Guinea sometime between 9000 and 6000 years ago, and a mid-Holocene date for the first appearance of pottery in Papua New Guinea (Bulmer 1985, 1991; Gorecki 1992; Gorecki et al. 1991; Swadling et al. 1989, 1991). These claims have been criticized on the basis that the finds are vertically displaced from higher in the profile, and because several of the sites for which the early finds are claimed are poorly published and inadequately dated (Spriggs 1996, 2001). However, they are worthy of discussion because they accord with the possibility of pre-Austronesian interaction between New Guinea and islands to the west. If crops dispersed from New Guinea into Southeast Asia in the early to mid-Holocene, then why could not pigs have been translocated in the other direction at the same date?

Unfortunately, the Aru Islands archaeological record is almost mute on this score. Pollen is not preserved in the cave sites of Lemdubu and Nabulei Lisa, nor in the Wangil Midden. Other palaeobotanical remains are rare. We therefore have no subsistence information about plant foods to complement the faunal sequences. Evidence for the introduction of domestic animals such as pig and dog, and by proxy the introduction of an agricultural economy, appears only in the last thousand years at Liang Nabulei Lisa and Wangil Midden. A putative indication of horticulture in the Aru Islands record is given by indirect evidence obtained from the Wangil swamp pollen core (Zone WGL 2: see Chapter 2). This sequence shows a distinct increase in charcoal perhaps indicating an increase in disturbance by fire and vegetation clearing at an inferred age of approximately 4400-3600 cal BP. Weed indicators such as some ferns, grass, and daisies also become more common in the core above this point. There is, however, nothing registered in the pollen record to demonstrate that this increased clearing is related to agriculture. It may simply reflect more intensive human activity near the site at a time when it was in the process of being removed from direct coastal influence and becoming less swampy.

The arrival of the Southeast Asian Neolithic as signalized by the introduction of pottery and/or domestic animals is barely registered in the archaeological record of Aru to date, and where it is, it occurs very late in the sequence. Pottery is confined to the last thousand years at the Wangil Midden and at Liang Nabulei Lisa. Three nondescript small body sherds in the Liang Lemdubu sequence may be slightly earlier, although in view of the size of the pottery sample, the fragment size, and the range for the dates in the upper three spits at Lemdubu, it would be foolhardy to argue for early pottery at this site.

\section{The Involvement of Aru as a Supplier of Bird of Paradise Feathers and Other Forest and Marine Products to World Markets Over the Last 2000 Years: the Metal Age, Pre-colonial, and Colonial Periods}

Perhaps the most unanticipated outcome of the Aru field program was the richness of the precolonial and colonial archaeological records. We began the systematic survey with the expectation that the control of the region by the Dutch East India Company during the historic period assured a good documentary coverage of the cultural record during this period. We discovered however, that at least for the later period (18th and 19th Centuries) - represented by sites such as Sirlasi and Jambu Air Lama in the southeast of the islands - the extent and scale of trade is poorly reflected in the historic records, which are either incomplete or absent. The presence of Indonesian Metal Age style pottery at midden/village sites such as Wangil, the considerable number of recent middens containing quantities of prestige goods such as European liquor bottles and Chinese porcelain, and the remarkable architecture of the Ujir ruins all attest to a vigorous exchange network at a scale 
that is largely otherwise undocumented. Some of these findings are summarized in Veth et al. (2000) and in revised form in Chapter 5, in Chapter 4 detailing the sites located during our survey of the Aru Islands, and in Chapter 6 on the Wangil Midden with its late Metal Age sequence.

We think it is likely that the Islamic-influenced structures of Ujir, situated adjacent to a protected deep water harbour, likely served as an entrepôt for the trade in birds of paradise, marine produce, and sago. The historic evidence for trade in other parts of Maluku, suggests that the original settlement could have been established by the late 15th century. This would fit well with the style of the numerous sherds of Chinese trade ware found scattered around the ruins. Whoever made the structures, it is clear that a settlement of this permanence and extent implies an involvement in regional, if not global, trading systems. The degree of Aru's involvement in these early trading systems has been historically neglected, due in part to the dominance of the north Moluccan and Bandanese trade-polities of the 15th and 16th centuries.

Lape $(2000 a, b)$ has documented a pre-colonial trade network centred in Banda. The presence of red slipped pottery from Banda in the early levels of the Wangil Midden demonstrates trade between the two islands as early as 500-800 BP (see Chapter 6 for further details). Three Dutch garrisons (and several churches) were established on Aru in the mid-late 17th century in an effort to control regional trade.

During our surveys around the Aru Islands, particularly on the east coast, we recorded a number of mounded and linear middens, some of considerable extent. Only one of these coastal sites has been excavated and analysed (Wangil Midden on Wamar Island - see Chapter 3). Many of the coastal middens were noted to contain both plain and decorated pottery and from the presence of imported ceramics were certainly used well into the 19th century. This was shown by the presence of glass bottles eroding from upper units that could be dated to the early to 19th century. The location of large village sites dating from about ca. $1800 \mathrm{AD}$ adjacent to the extensive reef systems on the east coast of Aru suggests a much greater involvement of this area with the wider trading world than is commonly appreciated, or than would be anticipated from the historic records relating to this later period. Yet, if we read Wallace's and other 19th century accounts carefully, we can see that Europeans were aware of the significance of this part of the archipelago. Wallace (1869:439) wrote:

... on the east coast are a great number of islands extending some miles beyond the mainland, and forming the 'blakang tana' or 'back country,' of the traders, being the principal seat of the pearl, tripang, and tortoise-shell fisheries.

Kolff (1840:175-6) gives an account of the scale of activity on the pearl banks in 1824 (cf. Spyer 2000:20-22). Oral history suggests that the large village sites we found in that area were decimated by a smallpox epidemic that passed through the region in the mid- to late-1800s and the communities then split their settlements into a number of smaller villages.

\section{Conclusions}

During the project we failed to find evidence of the probable earliest settlement of the Aru Plateau of Sahul, although with the burial of Lemdubu Woman - the earliest yet found in northern Sahul — we can get some idea of the appearance of the region's slightly later Pleistocene inhabitants. The stone artefacts from the early sites were particularly undiagnostic and unchanging over time, and provide little clue as to the cultural connections of the Pleistocene inhabitants of Aru. The fauna from the sites, on the other hand, gave a particularly rich picture of changing environments as Aru entered the drier 
period of the LGM, and then underwent climatic amelioration and the expansion of rainforest in the Holocene. Rising sea levels are also reflected in the freshwater and marine faunal record as the Aru Plateau became an island group cut off from its Sahulland roots by about 11,500 BP. We detected little or no trace of the spread of the Island Southeast Asian Neolithic and can attest to introduced animals such as pig, dog and deer only very late in our cultural sequences. We did, however, pick up a strong signal of the scale and importance of immediately pre-colonial and colonial period trading networks, including pre-1620s pottery imports from the Banda Islands. There is clearly much further potential for detailed work on the historical archaeology of Aru. Further research may also throw light both on the earliest period of occupation of what was then a low plateau on the edge of a continent and on the timing and impact of the spread of the Island Southeast Asian Neolithic in what by then was an archipelago. Without any doubt, Aru remains as fascinating - but hopefully not quite as mysterious — as it appeared to Alfred Russell Wallace on that January day in 1857.

\section{References}

Allen, J., and J.F. O'Connell. 2003. The long and the short of it: archaeological approaches to determining when humans first colonized Australia and New Guinea. Australian Archaeology 57:5-19.

Bellwood, P. 1997. Prehistory of the Indo-Malaysian Archipelago. 2nd Edition. Honolulu: University of Hawaii Press.

Bellwood, P., G. Nitihaminoto, G. Irwin, Gunadi, A. Waluyo, and D. Tanudirjo. 1998. 35,000 years of prehistory in the northern Moluccas. In G.-J. Bartstra (ed.), Bird's Head Approaches: Irian Jaya Studies, A Programme for Interdisciplinary Research, pp. 233-75. Rotterdam: A.A. Balkema. Modern Quaternary Studies in Southeast Asia 15.

Birdsell, J.B. 1977. The recalibration of a paradigm for the first peopling of Greater Australia. In J. Allen, J. Golson, and R. Jones (eds), Sunda and Sahul: Prehistoric Studies in Southeast Asia, Melanesia and Australia, pp. 113-67. London: Academic Press.

Bowler, J.M., H. Johnston, J.M. Olley, J.R. Prescott, R.G. Roberts, W. Shawcross and N.A. Spooner. 2003. New ages for human occupation and climatic change at Lake Mungo, Australia. Nature 421:837-840.

Brown, P., T. Sutikna, M.J. Morwood, R.P. Seojono, Jatmiko, E.W. Saptomo, and R.A. Due. 2004. A new small-bodied hominin from the Late Pleistocene of Flores, Indonesia. Nature 431: 1055-61.

Bulmer, S. 1985. Papuan pottery — an archaeological consideration. Bulletin of the Indo-Pacific Prehistory Association 6:123-32.

Bulmer, S. 1991. Variation and change in stone tools in the highlands of Papua New Guinea: the witness of Wanelek. In A. Pawley (ed.), Man and a Half: Essays in Pacific Anthropology and Ethnobiology in Honour of Ralph Bulmer, pp. 470-8. Auckland: The Polynesian Society.

Denham, T.P. 2003. The Kuk Morass: Multi-Disciplinary Investigations of Early to Mid Holocene Plant Exploitation at Kuk Swamp, Wahgi Valley, Papua New Guinea. Unpublished PhD thesis, Australian National University, Canberra.

Denham, T.P., S.G. Haberle, C. Lentfer, R. Fullagar, J. Field, M. Therin, N. Porch, and B. Winsborough. 2003. Origins of agriculture at Kuk Swamp in the Highlands of New Guinea. Science 301:189-93.

Glover, I. 1981. C Leang Burung 2 south Sulawesi. Modern Quaternary Research in SE Asia 6:1-38.

Gorecki, P. 1992. A Lapita smoke screen? In J.-C. Galipaud (ed.), Poterie Lapita et Peuplement: Actes du Colloque Lapita, Noumea, Nouvelle-Caledonie, Janvier 1992, pp. 27-47. Noumea: ORSTOM.

Gorecki, P., M. Mabin, and J. Campbell. 1991. Archaeology and geomorphology of the Vanimo coast, Papua New Guinea: preliminary results. Archaeology in Oceania 26:119-22.

Hope, G.S. 2001. Environmental change in the Late Pleistocene and later Holocene at Wanda Site, Soroako, South Sulawesi, Indonesia. Journal of Palaeogeography, Palaeoclimatology, Palaeoecology 17:129-45.

Hope, G.S., X. Sun, P.-M. Liew, A.P. Kershaw, W.A. van der Kaars, H. Takahara, M. McGlone, L.E. Heusser, and N. Miyoshi. 2004. History of vegetation and habitat change from the PEP II transect. Quaternary International 118-119:103-26.

Kershaw, A.P., S. van der Kaars, P. Moss, and X. Wang. 2002. Quaternary records of vegetation, biomass burning, climate and possible human impact in the Indonesian-Northern Australian region. In A.P. Kershaw, B. David, N. Tapper, D. Penny, and J. Brown (eds), Bridging Wallace's Line: The Environmental and Cultural History and Dynamics of the Southeast Asian-Australian Region, pp. 97-118. Reiskirchen: Catena Verlag. Advances in GeoEcology 34. 
Kolff, D.H. 1840. Voyages of the Dutch Brig of War 'Dourga' through the Southern and Little Known Parts of the Moluccan Archipelago ... during the Years 1825 and 1826. London: James Madden.

Lape, P.V. 2000a. Contact and Conflict in the Banda Islands, Eastern Indonesia, 11th to 17th Centuries. Unpublished PhD thesis, Brown University, Rhode Island.

Lape, P.V. 2000b. Political dynamics and religious change in the late pre-colonial Banda Islands, Eastern Indonesia. World Archaeology 32(1):138-55.

Leavesley, M.G. and J. Chappell. 2004. Buang Merabak: additional early radiocarbon evidence of the colonisation of the Bismarck Archipelago, Papua New Guinea. Antiquity 78(301). URL: http://antiquity.ac.uk/ProjGall/ leavesley/index.html

Morwood, M.J., P. O'Sullivan, F. Aziz, and A. Raza. 1998. Fission track age of stone tools and fossils on the east Indonesian island of Flores. Nature 392:173-76.

Morwood, M.J., F. Aziz, P. O'Sullivan, Nasruddin, D.R. Hobbs, and A. Raza. 1999. Archaeological and palaeontological research in central Flores, East Indonesia: results of fieldwork 1997-98. Antiquity 73:273-86.

Morwood, M.J., R.P. Seojono, R.G. Roberts, T. Sutikna, C.S.M. Turney, K.E. Westaway, W.J. Rink, J.-x. Zhao, G.D. van den Bergh, R.A. Due, D.R. Hobbs, M.W. Moore, M.I. Bird, and L.K. Fifield. 2004. Archaeology and age of a new hominin from Flores in Eastern Indonesia. Nature 431:1087-91.

O'Connor, S., M. Spriggs, and P. Veth. 2002. Excavation at Lene Hara establishes occupation in East Timor at least 30,000-35,000 years on: results of recent fieldwork. Antiquity 76:45-50.

O'Connor, S. and J. Chappell. 2003. Colonization and coastal subsistence in Australia and Papua New Guinea: different timing, different modes. In C. Sand (ed.), Pacific Archaeology: Assessments and Prospects. Proceedings of the International Conference for the 50th Anniversary of the First Lapita Excavation (July 1952), Koné-Nouméa 2002, pp. 15-32. Nouméa: Départment Archéologie, Service des Musées et du Patrimoine de NouvelleCalédonie. Le Cahiers de l'Archéologie en Nouvelle-Calédonie 15.

Spriggs, M. 1996. What is Southeast Asian about Lapita? In T. Akazawa and E. Szathmary (eds), Prehistoric Mongoloid Dispersals, pp. 324-48. Oxford: Clarendon Press.

Spriggs, M. 2001. Who cares what time it is? The importance of chronology in Pacific archaeology. In A. Anderson, I. Lilley and S. O'Connor (eds), Histories of Old Ages: Essays in Honour of Rhys Jones, pp. 237-49. Canberra: Pandanus Books, Australian National University.

Spyer, P. 2000. The Memory of Trade: Modernity's Entanglements on an Eastern Indonesian Island. Durham and London: Duke University Press.

Swadling, P., J. Chappell, G. Francis, N. Araho, and B. Ivuyo. 1989. A late Quaternary inland sea and early pottery in Papua New Guinea. Archaeology in Oceania 24:106-9.

Swadling, P., N. Araho, and B. Ivuyo. 1991. Settlements associated with the inland Sepik-Ramu Sea. Bulletin of the Indo-Pacific Prehistory Association 11:92-110.

Thorne, A.G. 1980. The longest link: human evolution in southeast Asia and the settlement of Australia. In J. Fox, R. Garnaut, P. McCawley and J. Mackie (eds), Indonesia: Australian Perspectives, pp. 35-43. Canberra: The Australian National University.

Thorne, A.G. 1989. The emergence of the Pacific peoples, in L.H. Schmitt, L. Freedman and N.W. Bruce (eds), The Growing Scope of Human Biology, pp. 103-111. Perth: Australasian Society for Human Biology.

Thorne, A., R. Grün, G. Mortimer, N.A. Spooner, J.J. Simpson, M. Mcculloch, L. Taylor and D. Curnoe. 1999. Australia's oldest human remains: age of the Lake Mungo 3 skeleton. Journal of Human Evolution 36:591-612.

Turney, C.S.M., M.I. Bird, L.K. Fifield, R.G. Roberts, M.A. Smith, C.E. Dortch, R. Grun, E. Lawson, L.K. Ayliffe, G.H. Miller, J. Dortch, and R.G. Cresswell. 2001. Early human occupation at Devil's Lair, southwestern Australia 50,000 years ago. Quaternary Research 55:3-13.

Veth, P., S. O'Connor, M. Spriggs, W. Nayati, A. Jatmiko, and H. Mohammad. 2000. The mystery of the Ujir site: insights into early historic settlement in the Aru Islands, Maluku. The Bulletin of the Australian Institute for Maritime Archaeology 24:125-32.

Wallace, A.R. 1869. The Malay Archipelago: The Land of the Orang-Utan and the Bird of Paradise. A Narrative of Travel, with Studies of Man and Nature. London: MacMillan. 